\title{
Educational System, Income Inequality and Growth: The Median Voter's Decision
}

Joilson Dias
Professor at the Universidade Estadual de Maringá

\section{RESUMO}

O objetivo deste artigo é analisar a utilização da política educacional no longo prazo como mecanismo para a redução da desigualdade de renda entre famílias de renda baixa, mediana e alta. Se a decisão sobre a política for endogeneizada, de acordo com o teorema do eleitor mediano, os resultados são os seguintes: i) o sistema educacional público para todos, apesar de garantir convergência de renda, produz uma menor taxa de crescimento da renda do eleitor mediano; ii) a combinação público-privado (sistema educacional híbrido) permite uma maior taxa de crescimento da renda do eleitor mediano, no entanto a desigualdade de renda é inerente a este sistema. Como resultado final, o eleitor mediano irá escolher o sistema público-privado, pois o crescimento da sua renda é maior, o que pode explicar a persistência e as diferenças na desigualdade de renda das economias.

\section{PALAVRAS-CHAVE}

educação, desigualdade de renda, crescimento

ABSTRACT

I analyze a long run educational policy as a mechanism to close the income gap among low, median and high-income families. If the choice is made endogenous by the use of the median voter theorem, the results are as follow: i) public education system guarantees income convergence, however the income growth rate of the median voter is smaller; ii) the combination public and private (hybrid) educational system allows faster income growth rate, but income inequality is almost the natural outcome. The ending result is that the combination public and private system will prevail, since the income growth rate of the median voter is higher in this system. This might explain the persistence and differences of income inequality among the economies.

KEY WORDS education, income inequality, growth

JEL Classification

H52, 128, O5 


\section{INTRODUCTION}

The objective of this paper is to introduce an endogenous policy related to educational system. ${ }^{1}$ The endogenous policy research framework can be best understood by the use of a counter example. The Romer (1990) model can be reggarded as an exogenous policy model since human capital, the most important input for technological advances, is not endogenously accumulated in the model. Its accumulation depends upon an educational policy. However, any educational policy effect will depend upon the educational system to be implemented. The objective here is to show how important the educational system quality and its form, public or private, on growth and inequality are.

The theory of endogenous policy linking the effects of income inequality on growth was proposed by Persson and Tabellini (1994). Under their view, income inequality lowers growth because it leads to policies that do not allow for full private appropriation of returns to investment. Here, I am concerned with the aspects of decision upon the educational system and its effect on income inequality and growth. Thus, income inequality as I perceive it is in part due to endogenous consumers' decision when choosing an educational system. The educational system is important because is through it that the economy accumulates human capital. The choice of the dimension between what should be public and private sets up the public investment in education. Their importance while either public or private was stablished by empirical evidence. Indeed the empirical evidence suggesting that growth rates can be improved by human capital investment were present in studies like Mankiw, Romer and Weil (1992), Levine and Renelt (1992), Barro and Lee (1993), Benhabib and Spiegel (1994) and Dias and McDermott (2003), among others. On the other side, there is also the benefit of public investment in education on income equality. Sylvester (2002) found that income inequality would greatly be reduced through public investment in education.

The medium voter theorem empirical test on growth and inequality was conducted by Milanovic (2000). The author found that greater income ine-

1 A review on the classical endogenous policy can be seen in PERSSON \& TABELLINI (1994). 
quality lowers growth because the redistribution policies sought by the median voter. Therefore, countries with greater income inequality redistribute more to poor causing growth rates to be lower.

According to the above views, public investment in education would foster growth and diminishes income inequality. Moreover, the median voter thus plays a role on redistributional policies. Here, we seek to understand the outcomes on growth and income inequality of the median voter's choice of an educational system.

The theoretical study that started building the bridge between growth, income inequality and educational system was done by Glomm and Ravikumar (1992). They focused on the basic formal schooling as the means for closing gaps between diverging productivity. Nonetheless, the authors did not consider the decision as having been made by a medium voter nor treated the matter simultaneously under public and private education system. Education quality may be an important aspect for existing private education system. In addition, we have that quality of the education is positively related to economic growth as found by Hanushek and Kimko (2000). Hence, the quality difference between the two systems may be one of the causes of income inequality. (JALLADE, 1978; LAM \& LEVISON, 1990; BARROS \& LAM, 1993; and SOUZA, 1994). ${ }^{2}$ The last point is precisely what I want to pursue in this paper. Hence, I will build a theory that posits it to be an endogenous decision done by the medium voter.

In this paper, the public investment is made endogenous to the consumers. The consumers decide how much to invest in public and private educational system or both. This is done through the introduction of the median vote rule. In such a model the median voter decides on the access to education system and its forms, whether public or public-private combination. The long-run objective of the consumer is to maximize income growth rate. This endogenous decision may lead the median voter consumer to choose a system where income inequality is present.

2 These papers directly or indirectly suggest that quality improvement in the education system is the main objective to be pursued over the long run as a mean for permanent productivity improvements and income inequality reduction. 
This paper is divided in six major sections. The forthcoming introduce the human capital theory necessary for the model. Section two presents a heterogeneous consumer theory. The medium voter theorem idea is developed in section three. The public education for all system is analyzed in section four. Section five presents the combination public-private education system analysis. The quality difference between public and private educational system is the focus of attention of section six.

\section{THE HUMAN CAPITAL THEOR}

The human capital theory to be used is the one proposed by Dias (1995 and 1996). The use of the theory proposed by the author is justified since it treats consumers as being heterogeneous in their knowledge levels. Their heterogeneity arises from aspects of reality where firms hire workers of different knowledge to form a team to produce goods of specified quality. However, by so doing, firms pay special attention to the amount of knowledge required to use the equipment. ${ }^{3}$ Thus, the firm objective it to match required knowledge by the equipment with embodied knowledge on workers. This assembled combination of knowledge levels forms what was called quantum of knowledge. The quantum of knowledge distribution reflects the heterogeneity of knowledge levels existing in the economy. This heterogeneity framework can be seen as an extension of the linear models where only one type of knowledge is considered. (ROMER, 1986; and REBELO, 1991).

The outcome of this theory is that in average each individual's productivity depends upon the quality of his or hers knowledge. Moreover, it is given by the following equation: ${ }^{4}$

$$
\mathrm{Y}(\mathrm{i})=\mathrm{Bi} \mathrm{H}_{\mathrm{i}}
$$

3 This view goes in hand with the capital-skill complementarity literature (e.g. ACEMOGLU, 1998).

4 See DIAS (1995).

Est. econ., São Paulo, 35(1):81-100, jan-mar 2005 
where $\mathrm{B}>0$ is a constant; i $\mathrm{E}[\ell, \mathrm{q}]$ is the index of quantum of knowledge, where $\ell$ is the lowest quantum of knowledge and $q$ the highest quantum of knowledge; and $\mathrm{H}_{\mathrm{i}}$ is the number of hours available of that specific quantum of knowledge.

Now, because productivity is attached to individuals with a specific quantum of knowledge, compatible consumer theory must be available. In the next section, we develop a compatible consumer theory.

\section{THE HETEROGENEOUS CONSUMERS' THEORY}

Equation ( 1 ) is equivalent to the income made by the individual with knowledge level i. To transform equation (1) in income per hour worked, we divided it by $\mathrm{H}_{\mathrm{i}}$. It now refers to the income generated by a specific class of workers.

$$
\mathrm{y}(\mathrm{i})=\mathrm{Bi}
$$

We assume the distribution function of the income per hour worked to be normal. This initial shape does not interfere in our analysis. Since, neither the initial nor the final shape is the centerpiece of the study. I am interested in seeing whether initial income inequality gap is closing over time or not.

The normal distribution function has a very well known shape that makes it more attractive and helpful. To simplify the analysis, even more, we will work with representative consumers belonging to low, median and high-income classes. According to the normal distribution function, the initial relationship between low, middle and high-income families is the following:

$$
\mathrm{q}=\sigma_{0} \mu, \mu=\sigma_{0} \ell \text { and } \mathrm{q}=\sigma_{0}^{2} \ell
$$

where $\sigma_{0}$ is the standard deviation of the distribution function. The condition that $\sigma_{0}>0$ simply states that there is an initial income inequality. 
Although I have assumed $\mathrm{f}(\mathrm{i})$ to be continuous, the focus of my attention will be on the three income classes $\ell, \mu$ and $\mathrm{q}$. By extension, I assume that there are three types of family/consumers in this economy, families with low, median and high-income. More specifically, each family has the following welfare function

$$
\begin{aligned}
& W=\int_{0}^{\infty} \frac{\left(c_{j}\right)^{1-\xi}-1}{1-\xi} e^{-\rho t} d t \quad \text { for } \xi=1, \text { and } \\
& W=\int_{0}^{\infty} \ln \left(c_{j}\right) e^{-\rho t} d t \quad \text { for } \xi=1 .
\end{aligned}
$$

where $\mathrm{c}_{\mathrm{j}}$ is the consumption of family $\mathrm{j}$ where $\mathrm{j}=\ell, \mu$ and $q$, or rather, families with low, median and high-income, respectively; $\xi$ is the parameter of the welfare function; $\rho$ is the discount or time preference rate assumed to be the same across the families.

\section{THE MEDIAN VOTER THEOREM}

The median voter theorem proposed by Bowen (1943) and Black (1958) states that under utility maximization conditions the subject of the anlysis must be centered on the behavior of the individuals in the median of the distribution, here represented by the median voter. This is because the public expenditure is democratically decided by a majority rule. Therefore, public expenditure always focuses upon the preferences of the median voter. In economics, the median voter is represented by the individual with medianincome.

In our case, the median-income family representative will choose a public or a public-private education system. The basic rule of the decision to be made by this median voter is as follows: he or she always gets back in education quality the same amount paid in tax.

The public system is the one to which everyone has access. However, in the combination public and private education system the following may hap- 
pen: a) low-income families will choose public education; median-income families will combine public and private education; and high-income families will choose private education.

\section{THE PUBLIC EDUCATION SYSTEM}

In the public education system, the following are assumed:

i) The public education system is accessible to everyone;

ii) The funding for improving the quality of the educational system will be provided by tax on median and high class income families;

iii) There is no intermediate cost between collecting tax and its transference to schools.

Families increase their quantum of knowledge by forgoing units of consumption and by improving the public school system by paying taxes. More precisely, each family/consumer accumulates quantum of knowledge in the following way:

$$
\begin{aligned}
& \dot{\ell}=\mathrm{y}(\ell)_{\mathrm{D}}-\mathrm{c}_{\ell}+\theta_{1} \mathrm{E}_{\mathrm{b}}, \text { where } \mathrm{y}(\ell)_{\mathrm{D}}=\mathrm{B} \ell \\
& \dot{\mu}=\mathrm{y}(\mu)_{\mathrm{D}}-\mathrm{c}_{\mu}+\theta_{2} \mathrm{E}_{\mathrm{b}}, \text { where } \mathrm{y}(\mu)_{\mathrm{D}}=\left(1-\tau_{\mu}\right) \mathrm{B} \mu \\
& \dot{\mathrm{q}}=\mathrm{y}(\mathrm{q})_{\mathrm{D}}-\mathrm{c}_{\mathrm{q}}+\theta_{3} \mathrm{E}_{\mathrm{b}}, \text { where } \mathrm{y}(\mathrm{q})_{\mathrm{D}}=\left(1-\tau_{\mu}\right) \mathrm{Bq}
\end{aligned}
$$

where $y(j) D$ with $j=\ell, \mu$ and $q$ is the family disposable income; $c_{j}$ is the family consumption; $\theta_{1}+\theta_{2}+\theta_{3}=1$ is the family share of the public school quality; and $\mathrm{E}_{\mathrm{b}}$ is the school quality. We assume the latter to be a direct function of the amount of money collected through income tax or simply,

$$
\mathrm{E}_{\mathrm{b}}=\tau_{\mu} \mathrm{y}(\mu)+\tau_{\mathrm{q}} \mathrm{y}(\mathrm{q})
$$


where $0<\tau_{\mu}, \tau_{\mathrm{q}}<1$ are the income tax rates on median and high-income class families.

Under this set up each family decision of how much to consume at any point in time and, by extension, to invest in quantum of knowledge is independent of each other. It is easy to notice, however, that by introducing a transformation cost between consumption and quantum of knowledge would not ad any extra information to the model.

The solution is quite simple. All we have to do is to set up a Hamiltonian function for each family and find its solution. More specifically, the Hamiltonian functions are obtained by using equation (4), subject to the constraint imposed by equations (5)-(7), and the side conditions imposed by equations $(3)$ and $(8)$ and the transversatility conditions. ${ }^{5}$ Once we have made the necessary substitution, the following set of discounted Hamiltonian functions comes up.

$$
\begin{aligned}
& \mathrm{H}_{\ell}=\left(\frac{\left(\mathrm{c}_{\ell}\right)^{1-\xi}-1}{1-\xi}+\psi\left[\mathrm{B} \ell-\mathrm{c}_{\ell}+\theta_{1} \tau_{\mu} \mathrm{B} \sigma_{0} \ell+\theta_{1} \tau_{\mathrm{q}} \mathrm{B} \sigma_{0}^{2} \ell\right]\right) \mathrm{e}^{-\mathrm{pt}} \\
& \mathrm{H}_{\mu}=\left(\frac{\left(\mathrm{c}_{\mu}\right)^{1-\xi}-1}{1-\xi}+\psi\left[\left(1-\tau_{\mu}\right) \mathrm{B} \mu-\mathrm{c}_{\mu}+\theta_{2} \tau_{\mu} \mathrm{B} \mu+\theta_{2} \tau_{\mathrm{q}} \mathrm{B} \sigma_{0} \mu\right]\right) \mathrm{e}^{-\mathrm{pt}} \\
& \mathrm{H}_{\mathrm{q}}=\left(\frac{\left(\mathrm{c}_{\mathrm{q}}\right)^{1-\xi}-1}{1-\xi}+\psi\left[\left(1-\tau_{\mathrm{q}}\right) \mathrm{Bq}-\mathrm{c}_{\mathrm{q}}+\theta_{3} \tau_{\mathrm{q}} \mathrm{Bq}+\theta_{3} \frac{\tau_{\mu}}{\sigma_{0}} \mathrm{~Bq}\right]\right) \mathrm{e}^{-p t}
\end{aligned}
$$

The solution to this set of Hamiltonian functions is well known and its derivation can be seen in Dias (1995). So for welfare function and transversality conditions to be satisfied, the following condition must be met: $B_{j}>\rho>(1-\xi) B_{j}$ for $j=j=\ell, \mu$ and $q$, where $B_{\ell}=\left(1+\theta_{1} \tau_{\mu} \sigma_{0}+\theta_{1} \tau_{q} \sigma_{0}^{2}\right)$, $\mathrm{B}_{\mu}=\left(1-\tau_{\mu}+\theta_{2} \tau_{\mu}+\theta_{2} \tau_{\mathrm{q}} \sigma_{0}\right)$ and $\mathrm{B}_{\mathrm{q}}=\left(1-\tau_{\mathrm{q}}+\theta_{3} \tau_{\mathrm{q}}+\theta_{3} \frac{\tau_{\mu}}{\sigma_{0}}\right) .{ }^{6}$ In other words, the productivity parameter has to be greater tnan the discount rate, while the elasticity of marginal utility $-\xi$ cannot be too close to zero. Henceforth, the transversatility is satisfied by this assumption.

The result I am looking forward to is the productivity growth rate and by extension, the consumption growth rate. One must recall that these two

5 CHIANG (1992).

6 The Appendix I shows the complete derivation for the low-income family as an example. 
variables are identical in this model, linearity condition. Hence, the solutions to the Hamiltonian functions produce the following growth rates:

$$
\begin{aligned}
& \gamma_{\ell}=\frac{c_{\ell}}{c_{\ell}}=\frac{\ell}{\ell}=\frac{1}{\xi}\left[\mathrm{B}\left(1+\theta_{1} \tau_{\mu} \sigma_{0}+\theta_{1} \tau_{\mathrm{q}} \sigma_{0}^{2}\right)-\rho\right] \\
& \gamma_{\mu}=\frac{c_{\mu}}{\mathrm{c}_{\mu}}=\frac{\dot{\mu}}{\mu}=\frac{1}{\xi}\left[\mathrm{B}\left(1-\tau_{\mu}+\theta_{2} \tau_{\mu}+\theta_{2} \tau_{\mathrm{q}} \sigma_{0}\right)-\rho\right] \\
& \gamma_{\mathrm{q}}=\frac{\mathrm{c}_{\mathrm{q}}}{\mathrm{c}_{\mathrm{q}}}=\frac{\dot{q}}{\mathrm{q}}=\frac{1}{\xi}\left[\mathrm{B}\left(1-\tau_{\mathrm{q}}+\theta_{3} \tau_{\mathrm{q}}+\theta_{3} \frac{\tau_{\mu}}{\sigma_{0}}\right)-\rho\right]
\end{aligned}
$$

In the above equations, there will be income transference from median and high-income families to low-income families equal to $\chi_{\ell}=\left(\theta_{1} \tau_{\mu} \sigma_{0}+\theta_{1} \tau_{q} \sigma_{0}^{2}\right) \geq 0$. The contribution to the public education quality by middle-income family is $\chi_{\mu}=\left(-\tau_{\mu}+\theta_{2} \tau_{\mu}+\theta_{2} \tau_{q} \sigma_{0}\right) \leq 0$; and $\chi_{\mathrm{q}}=\left(-\tau_{\mathrm{q}}+\theta_{3} \tau_{\mathrm{q}}+\theta_{3} \frac{\tau_{\mu}}{\sigma_{0}}\right) \leq 0$ is the contribution of the high-income family.

Under the median voter theorem, the median-income family will maximize its share of public education quality. In other words, the following is implied:

$$
\frac{\partial \chi_{\mu}}{\partial \theta_{2}}=\tau_{\mu}+\tau_{\mathrm{q}} \sigma_{0}=0 \Rightarrow \sigma_{0}=-\frac{\tau_{\mu}}{\tau_{\mathrm{q}}}
$$

Thus, in order to reduce initial income inequality $\left(\sigma_{0}\right)$, the tax rate imposed on median class must be smaller than the one on the high-income class. According to the median voter theorem, the decision is upon the median class. Hence, we do expect that $\tau_{\mu}<\tau_{\mathrm{q}}$ which assures the long run income convergence since we have the following: $\chi_{\mathrm{q}}=-\tau_{\mathrm{q}}<\chi_{\mu}=-\tau_{\mu}<\chi_{\lambda}=0$. This result is equivalent to substitute equation (15) into equations (12)-(14) and solve for their growth rate which give us $\gamma_{\ell}>\gamma_{\mu}>\gamma_{q}$. Hence, public education system guarantees income convergence through education quality as long as the income tax structure satisfies the median voter theorem. 


\section{THE PUBLIC AND PRIVATE SYSTEM}

The existence of public and private systems requires that some difference between these two exists. Indeed, the demand for a private education system requires the existence of some advantage over the public system; otherwise, there will be no demand for such system. Therefore, we need a behavioral theory for the existence of the two systems.

In our behavioral theory, families will choose any system such that the outcome of the system is superior to what families expend on it. Mathematically, it boils down to the following:

$$
\int_{\mathrm{t}}^{\mathrm{T}} \mathrm{E}_{\mathrm{v}} \mathrm{d} \mathrm{\imath}>\int_{\mathrm{t}}^{\mathrm{T}} \mathrm{E}_{\mathrm{b}} \mathrm{d} \mathrm{\imath}=\int_{0}^{\mathrm{t}} \mathrm{I}(\mathrm{j}) \mathrm{d} \mathrm{\imath}, \text { where } j=\ell, \mu, q
$$

According to equation (19) for every dollar invested in education quality, $\int_{0}^{\mathrm{t}} \mathrm{I}(\mathrm{j}) \mathrm{d} \mathrm{\imath}$, more than a dollar will be received back in the private system, $\int_{\mathrm{t}}^{\mathrm{T}} \mathrm{E}_{\mathrm{v}} \mathrm{d} \mathrm{l}>\int_{0}^{\mathrm{t}} \mathrm{I}(\mathrm{j}) \mathrm{d} \mathrm{l}$. Nonetheless, I assume it to be a dollar for a dollar for the public system, $\int_{\mathrm{t}}^{\mathrm{T}} \mathrm{E}_{\mathrm{b}} \mathrm{dl}=\int_{0}^{\mathrm{t}} \mathrm{I}(\mathrm{j}) \mathrm{dl} \cdot{ }^{7}$ Hence, there is a quality difference between the two systems and that explains the existence of the private system parallel to the public one.

Thus, according to this behavioral theory, families will choose the system in which the expected return of their future income is superior to what they expend on quality improvement of the educational system. Thus, I expect the low-income family always to use the public system, since it requires no payment. The median-income family is expected to combine public and pri-

7 To simplify we have assumed the rate of discount to be zero. The integral from zero to time $t$ represents the past cost or investment in quality made in education; while the integral from time $t$ to the ending $T$ represents the outcome to be received from that investment. In sum, at point $t$ end the knowledge accumulation and starts the income generation from the knowledge accumulated that will last until $\mathrm{T}$. 
vate systems in order to maximize its income growth. On the other hand, the high-income family is expected to use the private school system.

For while I will posit that low and median-income families will share the public education system with the high-income family choosing only private education system. Under these assumptions our model becomes interesting because the cross subsidy among the classes can be more easily analyzed. However, I return to this subject in section six latter on. Under these assumptions, the following conditions would be obeyed:

i) The quality of the public system attended by low-income families is given by

$$
\mathrm{E}_{\mathrm{b} \ell}=(1-\theta)\left[\tau_{\mu \mathrm{b}} \mathrm{y}(\mu)+\tau_{\mathrm{qb}} \mathrm{y}(\mathrm{q})\right]=(1-\theta) \mathrm{E}_{\mathrm{b}}
$$

where $\theta \varepsilon[0,1]$ represents the share between the low and median-income families; $\tau_{\mu \mathrm{b}} \mathrm{y}(\mu)$ is the amount of tax paid by median-income family; $\tau_{\mathrm{qb}} \mathrm{y}(\mathrm{q})$ is the amount of tax paid by high-income family.

ii) The quality of public and private systems attended by median-income family is given by

$$
\mathrm{E}_{\mu \nu}=\phi \tau_{\mu v} \mathrm{y}(\mu)+\theta\left[\tau_{\mu \mathrm{b}} \mathrm{y}(\mu)+\tau_{\mathrm{qb}} \mathrm{y}(\mathrm{q})\right]=\phi \tau_{\mu v} \mathrm{y}(\mu)+\theta \mathrm{E}_{\mathrm{b}}
$$

where $\phi>1$ is the parameter that represents the quality of the private school system; $\tau_{\mu v} \mathrm{y}(\mu)$ is the share of income that goes to the private school system; $\theta\left[\tau_{\mu b} \mathrm{y}(\mu)+\tau_{\mathrm{qb}} \mathrm{y}(\mathrm{q})\right]$ is the share of public school system used by median-income family.

i) The quality of the private system attended by high-income family is given by

$$
\mathrm{E}_{\mathrm{qv}}=\phi \tau_{\mathrm{qv}} \mathrm{y}(\mathrm{q})
$$

where $\phi>1$ defined above; $\tau_{\mathrm{qv}} \mathrm{y}(\mathrm{q})$ is the share of income that goes to the private school system. 
The family's disposable incomes are the following:

$$
\begin{aligned}
& \mathrm{y}(\ell)_{\mathrm{D}}=\mathrm{B} \ell \\
& \mathrm{y}(\mu)_{\mathrm{D}}=\left(1-\tau_{\mu \mathrm{b}}-\tau_{\mu \mathrm{v}}\right) \mathrm{B} \mu \\
& \mathrm{y}(\mathrm{q})_{\mathrm{D}}=\left(1-\tau_{\mathrm{qb}}-\tau_{\mathrm{qv}}\right) \mathrm{Bq}
\end{aligned}
$$

The accumulation function for each family is given by the following set of equations:

$$
\begin{gathered}
\dot{\ell}=\mathrm{y}(\ell)_{\mathrm{D}}-\mathrm{c}_{\ell}+\mathrm{E}_{\mathrm{b} \ell} \\
\dot{\mu}=\mathrm{y}(\mu)_{\mathrm{D}}-\mathrm{c}_{\mu}+\mathrm{E}_{\mu \mathrm{v}} \\
\dot{\mathrm{q}}=\mathrm{y}(\mathrm{q})_{\mathrm{D}}-\mathrm{c}_{\mathrm{q}}+\mathrm{E}_{\mathrm{qv}}
\end{gathered}
$$

The welfare function to be maximized is given by equation (4). The constraints are given by equations (26)-(28) and the side conditions expressed by equations (23)-(25) and equation (3). It is worth to remember that each family makes its own decision. Thus, each one has to maximize its own discounted Hamiltonian. The set of Hamiltonians to be maximized is the following:

$$
\begin{aligned}
& \mathrm{H}_{\ell}=\left(\frac{\left(\mathrm{c}_{\ell}\right)^{1-\xi}-1}{1-\xi}+\psi\left[\mathrm{B} \ell-\mathrm{c}_{\ell}+(1-\theta)\left(\tau_{\mu \mathrm{b}} \mathrm{B} \sigma_{0} \ell+\tau_{\mathrm{qb}} \mathrm{B} \sigma_{0}^{2} \ell\right)\right]\right) \mathrm{e}^{-\mathrm{pt}} \\
& \mathrm{H}_{\mu}=\left(\frac{\left(\mathrm{c}_{\mu}\right)^{1-\xi}-1}{1-\xi}+\psi\left[\left(1-\tau_{\mu \mathrm{b}}-\tau_{\mu \mathrm{v}}\right) \mathrm{B} \mu-\mathrm{c}_{\mu}+\phi \tau_{\mu \mathrm{v}} \mathrm{B} \mu+\theta\left(\tau_{\mu \mathrm{b}} \mathrm{B} \mu+\tau_{\mathrm{qb}} \sigma_{\mathrm{o}} \mathrm{B} \mu\right)\right]\right) \mathrm{e}^{-\rho \mathrm{t}} \\
& \mathrm{H}_{\mathrm{q}}=\left(\frac{\left(\mathrm{c}_{\mathrm{q}}\right)^{1-\xi}-1}{1-\xi}+\psi\left[\left(1-\tau_{\mathrm{qb}}-\tau_{\mathrm{qv}}\right) \mathrm{Bq}-\mathrm{c}_{\mathrm{q}}+\phi \tau_{\mathrm{qv}} \mathrm{Bq}\right]\right) \mathrm{e}^{-\rho \mathrm{pt}}
\end{aligned}
$$

Again, I had skipped the intermediate steps of the derivation of this set of Hamiltonians. The outcome obtained is the growth rates of the families' income or

$$
\gamma_{\ell}=\frac{\dot{c_{\ell}}}{\mathrm{c}_{\ell}}=\frac{\dot{\ell}}{\ell}=\frac{1}{\xi}\left[\mathrm{B}\left(1+(1-\theta)\left(\tau_{\mu \mathrm{b}} \sigma_{0}+\tau_{\mathrm{qb}} \sigma_{0}^{2}\right)\right)-\rho\right]
$$




$$
\begin{aligned}
& \gamma_{\mu}=\frac{\mathrm{c}_{\mu}}{\mathrm{c}_{\mu}}=\frac{\dot{\mu}}{\mu}=\frac{1}{\xi}\left[\mathrm{B}\left(1-\tau_{\mu \mathrm{b}}-\tau_{\mu v}+\phi \tau_{\mu v}+\theta\left(\tau_{\mu b}+\tau_{\mathrm{qb}} \sigma_{\mathrm{o}}\right)\right)-\rho\right] \\
& \gamma_{\mathrm{q}}=\frac{\mathrm{c}_{\mathrm{q}}}{\mathrm{c}_{\mathrm{q}}}=\frac{\mathrm{q}}{\mathrm{q}}=\frac{1}{\xi}\left[\mathrm{B}\left(1-\tau_{\mathrm{qb}}-\tau_{\mathrm{qv}}+\phi \tau_{\mathrm{qv}}\right)-\rho\right]
\end{aligned}
$$

According to equations (31)-(34) the following conditions: $\chi_{\ell v}=\left[(1-\theta)\left(\tau_{\mu b} \sigma_{0}+\tau_{\mathrm{gb}} \sigma_{0}^{2}\right)\right] ; \quad \chi_{\mu v}=\left[-\tau_{\mu \mathrm{b}}-\tau_{\mu \mathrm{v}}+\phi \tau_{\mu \mathrm{v}}+\theta\left(\tau_{\mu \mathrm{b}}+\tau_{\mathrm{qb}} \sigma_{\mathrm{o}}\right)\right] ;$ and $\chi_{\mathrm{qv}}=\left\lfloor-\tau_{\mathrm{qb}}-\tau_{\mathrm{qv}}+\phi \tau_{\mathrm{qv}}\right\rfloor$ are verified.

To be coherent with the median voter theorem and our behavioral theory, the median-income family receives back in public school quality the same amount it has paid in tax. This is equivalent to a maximization of $\chi_{\mu v}$ with respect to access to the public education system. The following result is thus obtained:

$$
\frac{\partial \chi_{\mu \mathrm{v}}}{\partial \theta}=\tau_{\mu \mathrm{b}}+\tau_{\mathrm{qb}} \sigma_{0}=0 \Rightarrow \sigma_{0}=-\frac{\tau_{\mu \mathrm{b}}}{\tau_{\mathrm{qb}}}
$$

Recalling the definition of $\phi$, the rate of return for attending private school system is greater than one. Thus, we can make $\phi=1+v$, where $v>0$ represents the net rate of return for attending private system. Hence, $v$ sets the quality difference between private and public education systems. By using this condition and equation (35) we have the following: $\chi_{\ell v}=0$; $\chi_{\mu v}=\left\lfloor-\tau_{\mu \mathrm{b}}+v \tau_{\mu v}\right\rfloor$; and $\chi_{\mathrm{qv}}=\left\lfloor-\tau_{\mathrm{qb}}+v \tau_{\mathrm{qv}}\right\rfloor$. Now, if the net return of private education is higher than the tax paid by the median and high-income families, then convergence will not happen. As a matter of fact if $\tau_{\mu \mathrm{b}}=\nu \tau_{\mu \mathrm{v}}$ and $\tau_{\mathrm{qb}}=\nu \tau_{\mathrm{qv}}$, the income distribution will stay the same. For convergence to happen the following conditions must be met: a) $\chi_{\mu \nu}<0$; b) $\chi_{\mathrm{qv}}<0$; and $\left|\chi_{\mu v}\right|<\left|\chi_{\mathrm{qv}}\right|$ or $\frac{\tau_{\mu \mathrm{b}}}{\tau_{\mu v}}>\frac{\tau_{\mathrm{qb}}}{\tau_{\mathrm{qv}}}>v$. The income tax on median and high-income families used to foster public education must exceed the amount of their income invested in private education. In sum, it requires public investment in education that closes the gap quality between the two systems. 
It is interesting to notice that even under the above convergence condition we have that $\chi_{\mu v}<\chi_{\mu}$ and $\chi_{\mathrm{qv}}<\chi_{\mathrm{q}}$. In other words, the income growth rate under the combined public and private education system will be higher, especially for median and high-income families, when compared to the public educational system only.

\section{THE EDUCATION QUALITY DIFFERENCE}

The objective of this section is two folds. First, it is to verify under what conditions our assumptions on low and median-income families sharing public education and high-income families using just the private educations system are valid. Second, it is to analyze under what circumstances the quality differences between public and private education emerges. The analysis will be done by each family.

\subsection{Low-Income Families}

To analyze the family willingness to move from a system to the other is equivalent to compare the benefit difference between the two systems. It is important to have in mind that the families have as objective to accumulate the same amount of knowledge in whatever system. In the low-income family case, moving from public to private educational system is equivalent to compare the following two equations:

$$
\begin{aligned}
& \frac{\dot{\ell}}{\ell}=\mathrm{y}_{\ell}-\mathrm{c}_{\ell}+(1-\theta) \mathrm{E}_{\mathrm{b}} \\
& \frac{\dot{\ell}}{\ell}=\left(1-\tau_{\ell v}\right) \mathrm{y}_{\ell}-\mathrm{c}_{\ell}+\mathrm{E}_{\ell v}
\end{aligned}
$$

Equations (36) and (37) are the knowledge accumulation under public and private education, respectively. Specifically in equation (37), $\mathrm{E}_{\ell v}$ represents the quality of the private educational system attended by poor family. By equating these two equations and recalling that $\mathrm{E}_{\ell v}=(1+\mathrm{n}) \mathrm{Eb}$ the result is $\tau_{\ell v} \mathrm{y}_{\ell}=(v+\theta) \mathrm{E}_{\mathrm{b}}$. The public education quality can be represented by an in- 
come transference such that $\mathrm{s}_{\ell} \mathrm{y}_{\ell}=\mathrm{E}_{\mathrm{b}}$, where $0<\mathrm{s}_{\ell}<1$. Combining the last two results, the following turns out

$$
\frac{\tau_{\ell v}}{\mathrm{~s}_{\ell}}=v+\theta
$$

It is easy to see that the low-income family is willing to invest in private education the same amount received as income transference through public education or $\frac{\tau_{\ell v}}{\mathrm{~s}_{\ell}}=1$. In this case, we have $(1-\theta)=v$. In another words, by giving up the income transference through public education, poor family must invest the same amount of their own income to get back the same quality share when nothing on their own is invested. ${ }^{8}$

Now let us change equation (37) to capture the sharing between public and private system instead of just private system as previously done.

$$
\frac{\dot{\ell}}{\ell}=\left(1-\tau_{\ell v}\right) \mathrm{y}_{\ell}-\mathrm{c}_{\ell}+\theta_{\ell}(1-\theta) \mathrm{E}_{\mathrm{b}}+\left(1-\theta_{\ell}\right) \mathrm{E}_{\ell v}
$$

Now, $\theta$ is the share of public education with median income family and $\theta_{\ell} \varepsilon(0,1)$. It represents the percentage of public education that our poor family is willing to give up in exchange for private education. By equating equations (36) and (39) and using the previous conditions that $\mathrm{s}_{\ell} \mathrm{y}_{\ell}=\mathrm{E}_{\mathrm{b}}$ and $\frac{\tau_{\ell v}}{\mathrm{~s}_{\ell}}=1$, then $\theta_{\ell}=1-\frac{1}{v+\theta}$. When $0=\mathrm{n}+\theta=1$, it implies that $\theta_{\ell} \leq 0$. In this case there will be no willingness to attend private education. When low-income family's share of public education is very high and together with that there is a high quality difference between public and private educational system such that $v+\theta>1$ then $\theta_{\ell} \leq 0$. In this case, lowincome families will attend public and private educational systems. Thus, our assumption along the last section is equivalent to +1 or the same as stating that the combined access to public education and quality of private

8 This result is the same under the public education for all system when compared to moving to private education. There the result is $v=\theta_{3}$ 
system does not justify low-income families to attend private education. It is interesting to notice that more access to public education by low-income family leads to a combination of public-private educational system. This might be equivalent to low-income family to acquire the status of medianincome family by attending a better public education system.

\subsection{Median-Income Family}

The median-income family is the one that decides the quality of the private education system through its willingness to invest in it. This is very reasonable, since their decision of combining both systems is the key for emerging private education system and therefore enabling families combines both. The difference between the two systems under median-income family decision relay on the quality difference of the systems. . The analysis will seek the conditions under which median-income family will migrate from public to public-private combination as proposed by our assumptions. The two set of equations to be analyzed are

$$
\begin{aligned}
& \frac{\dot{\mu}}{\mu}=\left(1-\tau_{\mu b}\right) y_{\mu}-c_{\mu}+\theta E_{b} \\
& \frac{\dot{\mu}}{\mu}=\left(1-\tau_{\mu b}-\tau_{\mu v}\right) y_{\mu}-c_{\mu}+\theta_{\mu} \theta E_{b}+\left(1-\theta_{\mu}\right) E_{\ell v}
\end{aligned}
$$

Where equation (40) represents the knowledge accumulation under public education, equation (41) is the combination public-private one. Here, $\theta$ is the share of public education with the poor family and $\theta_{\mu} \varepsilon[0,1]$ represents how much public education will be exchanged by private education. By recalling that public education quality can be represented by $\mathrm{s}_{\mu} \mathrm{y}_{\mu}=\mathrm{E}_{\mathrm{b}}$ and that $\frac{\tau_{\mu v}}{\mathrm{~S}_{\mu}}=1$, the median-income family is willing to invest in private education the same amount of the income being giving up under public education. Under these conditions the result is $\theta_{\mu}=1+\frac{1}{\theta-v-1}$. In this case $\theta_{\mu}$ will be positive for $v>\theta$, the quality of the private education system has to be superior to the public system attended by the median-income family. 
A much direct approach can be seen by replacing equation (41) by the following one:

$$
\frac{\dot{\mu}}{\mu}=\left(1-\tau_{\mu \mathrm{b}}-\tau_{\mu v}\right) \mathrm{y}_{\mu}-\mathrm{c}_{\mu}+\theta \mathrm{E}_{\mathrm{b}}+\mathrm{E}_{\ell v}
$$

Now, the median-income family does not have to give up any access to public education in order to attend private education. Using the condition that

$\mathrm{s}_{\mu} \mathrm{y}_{\mu}=\mathrm{E}_{\mathrm{b}}$ the result is $\frac{\tau_{\mu v}}{\mathrm{~s}_{\mu}}=1+v$. The investment made by the representative median-income family in excess of the return provide by the public education will be the key for the quality of the private education system. This decision made by the median-income family will set up the quality difference between public and private one. Thus, the quality is endogenous to the median-income family decision to invest in private education.

\subsection{High-Income Family}

Under our made assumption high-income family will invest only on private education system. Here, I compare this condition with the one that the family attends both public and private education systems. This is equivalent to compare the following two equations:

$$
\begin{aligned}
& \frac{\dot{q}}{\mathrm{q}}=\left(1-\tau_{\mathrm{qb}}-\tau_{\mathrm{qv}}\right) \mathrm{y}_{\mathrm{q}}-\mathrm{c}_{\mathrm{q}}+\mathrm{E}_{\mathrm{qv}} \\
& \frac{\dot{\mathrm{q}}}{\mathrm{q}}=\left(1-\tau_{\mathrm{qb}}-\tau_{\mathrm{qv}}\right) \mathrm{y}_{\mathrm{q}}-\mathrm{c}_{\mathrm{q}}+\theta_{\mathrm{q}} \mathrm{E}_{\mathrm{qv}}+\left(1-\theta_{\mathrm{q}}\right) \theta_{3} \mathrm{E}_{\mathrm{b}}
\end{aligned}
$$

The variable $\theta_{\mathrm{q}}$ represents the amount of private education quality that median-income family is willing to give up for public education. However, the limit to access public education is given by $\theta 3$ its share under public education for all. The result is $\theta_{3}=1+v$. In this case, it requires that the public education must have the same quality as the private education system. Hence, our made assumption seems reasonable under this set up. 


\section{CONCLUSION}

In a democratic system where the public expenditure tries to satisfy the median voter theorem, we have two outcomes depending upon the existing education system. First, if the adopted system is public education for all, income inequality may be reduced over the long run through education quality, since it will be more accessible to everyone. Second, if there is simultaneously public and private education system, income inequality will be reduced only under very strict conditions.

If the choice of the system is up to the median voter, then the system to be chosen is the combined public and private education system. This combination allows a greater income growth rate when compared to the public system alone. Hence, over the long run the median voter will be better off under the combination of public and private education system. Moreover, the median voter will also set up the quality difference between the public and private system. This last outcome may explain the persistence in income inequality over time and across-countries.

\section{APPENDIX: THE HOUSEHOLD MAXIMIZATION PROCESS}

Here, I derive the household maximization process for the low-income family as a way of demonstrating how the transversatility condition is satisfied. Consider the Hamiltonian function given by equation (9). The solution is given by the following set of equations:

$$
\text { i) } \mathrm{c}^{-\xi}=\psi \text {; ii) } \dot{\psi}=\rho \psi-\psi \mathrm{B}_{\ell} \text {; and iii) } \operatorname{Lim}_{\mathrm{t} \rightarrow \infty} \psi(\mathrm{t}) \ell(\mathrm{t}) \mathrm{e}^{\rho \mathrm{t}}=0 \text {. }
$$

where $\mathrm{B}_{\ell}=\left(1+\theta_{1} \tau_{\mu} \sigma_{0}+\theta_{1} \tau_{\mathrm{q}} \sigma_{0}^{2}\right)$. By differencing equation $\left.\mathrm{i}\right)$ with regards to time and plugging this result into equation ii) we have iv) $\frac{\mathrm{c}}{\mathrm{c}}=\frac{\dot{\ell}}{\ell}=\frac{1}{\xi}\left(\mathrm{B}_{\ell}-\rho\right)$. 
The transversatility, equation iii), is easily satisfied by the following condition: v) $\frac{\psi}{\psi}+\frac{\ell}{\ell}<\rho$. Dividing equation ii) by $\psi$ and substituting into equation $\mathrm{v}$ ) and using equation iv) we get vi) $(1-\xi) \mathrm{B}_{\ell}<\rho$. The positive growth rate of knowledge accumulation implies that $\mathrm{B}_{\ell}>\rho$. Together these two results imply that vii) $\mathrm{B}_{\ell}>\rho>(1-\xi) \mathrm{B}_{\ell}$. This is easily satisfied for $\xi>1$. However, for $0<\xi<1$ equation vii) has to be made in assumption.

\section{REFERENCES}

ACEMOGLU, D. Why technologies complement skills? Directed technical change and wage inequality. Quarterly Journal of Economics, v. 113, n. 4, p. 1055-1089, 1998.

BARRO, R. J.; LEE, J. W. Losers and winners in economic growth. Working Paper 4341, NBER, 1993.

BARROS, R. P.; LAM, D. Desigualdade de renda, desigualdade em educação e escolaridade das crianças no Brasil. Pesquisa e Planejamento Econômico, v. 23, n. 2, p. 191-218, 1993.

BENHABIB, J.; SPIEGEL, M. M. The role of human capital in economic development evidence from aggregate cross-country data. Journal of Monetary Economics, v. 34, n. 1, p. 143-173, 1994.

BLACK, D. The theory of commitees and elections. Cambridge: Cambridge University Press, 1958.

BOWEN, H. R. The interpretation of voting in the allocation of economic resources. Quarterly Jourmal of Economics, v. 58, n. 1, p. 27-48, 1943.

CHIANG, A. C. Elements of dynamic optimization. New York: McGrawHill, Inc., 1992.

DIAS, J. The quantum of knowledge theory. Revista Brasileira de Economia, v. 49, n. 1, p. 109-126, 1995.

. Crescimento econômico estocástico: a teoria do quantum de conhecimento. Pesquisa e Planejamento Econômico, v. 26, n. 1, p. 2754, 1996.

DIAS, J.; McDERMOTT, J. Aggregate threshod effects and the importance of human capital in economic development. SBE-XXV Encontro Brasileiro de Econometria, Porto Seguro, 2003.

DOWRICK, S. Technological catch up and diverging incomes: patterns of economic growth 1960-88. The Economic Journal, v. 102, n. 3, p. 600-610, 1992. 
CHIANG, A. C. Dynamic optimization. New York: McGraw-Hill, 1992.

GLOMM, G.; RAVIKUMAR, B. Public versus private investment in human capital: endogenous growth and income inequality. Journal of Political Economy, v. 100, n. 4, p. 818-834, 1992.

HANUSHEK, E. A.; KIMKO, D. Schooling, labor-force quality, and the growth of nations. The American Economic Review, v. 90, n. 5, p. 1184-1208, 2000.

JALLADE, J. P. Educação de primeiro grau e desigualdade de renda no Brasil: perspectivas a longo prazo. Pesquisa e Planejamento Econômico, v. 8, n. 3, p. 561-598, 1978.

LAM, D.; LEVISON, D. O declínio na desigualdade da escolaridade no Brasil e seus efeitos na desigualdade de rendimentos. Revista de Econometria, v. 10, n. 2, p. 243-278, 1990.

LEVINE, R.; RENELT, D. A sensitivity analysis of cross-country growth regressions. The American Economic Review, v. 82, n. 4, p. 942-963, 1992.

LUCAS, R. On the mechanics of economic development. Journal of Monetary Economics, v. 22, n. 1, p. 3-42, 1988.

MANKIW, N. G.; ROMER, D.; WEIL, D. N. A contribution to the empirics of economic growth. The Quartely Journal of Economics, v. 107 , n. 2, p. $407-437,1992$.

MILANOVIC, B. The median-voter hyphotesis, income inequality, and income redistribution: an empirical test with the required data. $E u$ ropean Journal of Political Economy, v. 16, n. 3, p. 367-410, 2000.

PERSSON, T.; TABELLINI, G. Is inequality harmful for growth? The American Economic Review, v. 84, n. 3, p. 600-621, 1994.

REBELO, S. Long-run policy analysis and long-run growth. Journal of Political Economy, v. 96, n. 2, p. 500-521, 1991.

ROMER, P. Increasing returns and long-run growth. Journal of Political Economy, v. 94, n. 3, p. 1002-1037, 1986.

SOUZA, A. M. Educational policies: efficiency and equity issues. Revista Brasileira de Economia, v. 48, n. 4, p. 411-420, 1994.

SYLVESTER, K. Can education expenditure reduce income inequality? Economics of Education Review, v. 21, n. 1, p. 43-52, 2002.

I would like thank the very helpful suggestions made by Luís Eduardo Afonso and Maria Helena Ambrosio Dias, and the financial support provided by CNPq.

(Recebido em outubro de 2003. Aceito para publicação em janeiro de 2005). 